\title{
Native plant and weed diversity in forest remnants affected by Tradescantia fluminensis management
}

\author{
C.S. Lusk, G.A. Hurrell and S.L. Lamoureaux \\ AgResearch, Lincoln Science Centre, Private Bag 4749, Christchurch, New Zealand \\ Corresponding author: Carolyn.lusk@agresearch.co.nz
}

\begin{abstract}
This study aimed to determine the effects of different management practices for Tradescantia fluminensis in lowland podocarp/broadleaf forest remnants in the lower North Island. Fourteen $50 \mathrm{~m}$ line transects, across eight sites, were established in April 2009 and assessed annually until 2012. Management practices prior to and during the study period were documented. Over the four assessments, changes in the numbers of native plant seedlings and species differed greatly between management practices as did the percent cover of Tradescantia and other weeds. Native species diversity improved more and the abundance of Tradescantia and other weeds increased less, in forests that were less disturbed and where careful on-going control was carried out, than in forests with more disturbance prior to or during control operations. Effective monitoring of both weeds and native plants is essential to enable the outcome of weed management practices to be measured.
\end{abstract}

Keywords species abundance, monitoring, regeneration, herbicide.

\section{INTRODUCTION}

Tradescantia or wandering Jew (Tradescantia fluminensis Vell.), a South American native plant, is a serious environmental weed in New Zealand lowland forest remnants. It is a perennial groundcover that forms dense mats of vegetation that suppress native seedlings by reducing light, thus interfering with forest succession (McCluggage 1998; Standish 2001). The control of Tradescantia on public land in New Zealand is carried out by forest managers from the Department of Conservation, Regional Councils, City Councils and various Community Groups (e.g. Weedbusters). In 2009 with the imminent release of a biocontrol agent, the Tradescantia leaf beetle (Neolema ogloblini), a nationwide survey of 36 forest managers from these organisations was undertaken (C.S. Lusk, unpublished data) to determine who was actively controlling Tradescantia and what control methods and monitoring methods were being used. The survey revealed that approaches to controlling Tradescantia varied in geographic scale as well as herbicide type and methods of application. Twenty-two of the $36(61 \%)$ managers were controlling Tradescantia. Triclopyr $\left(\right.$ Grazon $^{\circledR}$, $600 \mathrm{~g}$ ai/litre, E.C. typically used at an application rate of $0.6 \%$ ) was the herbicide most used (17 of the 22) and generally involved blanket or spot applications followed by repeated spot spraying at varying intervals over a number of years. In a few cases manual control was used, but this was generally confined to smaller infestations or 
public areas where herbicides could not be used, because this method is not practical for largescale infestations.

Only four of the 36 managers were monitoring the result of their management and of these, only two were doing so quantitatively. Typically, the managers assessed the effect only in terms of reductions in the abundance of the Tradescantia and not on the impacts on native plants or other weeds. This is apparently not unusual, judging by the scarcity of published literature on the impacts on native plants of weed control operations, and of those published, most have focused only on the effects on the target weed and not the impacts on native biodiversity (Kettenring \& Adams 2011). In their review of 355 studies, Kettenring \& Adams (2011) found less than $30 \%$ of studies considered the outcomes on both the invasive weed(s) and the native plants. Most studies (80\%) reported results from scientific experiments and not from real restoration/weed management projects, and many studies had limited scope - using small plots and reporting short term responses $(52 \%$ were $<1$ year duration). These limitations had in some cases resulted in the wrong conclusions being drawn from the experiments. Furthermore, it was found that forest restoration sites where herbicides were used were often invaded by other exotic weed species, frequently resulting in no improvement in native plant diversity (Reid et al. 2009).

To redress the lack of information on the effect of Tradescantia management on native plant diversity, this study over 4 years measured the outcomes of different strategies for controlling Tradescantia in terms of the native plant and weed diversity.

\section{METHODS}

Eight study sites were selected from those remnant forests identified in the survey. The selection was based on information supplied by the forest manager, with each site having had recent Tradescantia control and where the forest type, management practice and effects on Tradescantia and native species had varied. The management practices were not influenced in any way. The sites were located in Wellington
(2), Wairarapa (4) and Manawatu (2). Fourteen transects in total were set up in April 2009 across the eight sites (Table 1) where recent control operations (herbicide or manual removal) had been documented. Information on spray history was collected (Table 2).

On each transect a $50 \mathrm{~m}$ tape measure was laid between permanent locating pegs and at $5 \mathrm{~m}$ intervals ( 11 per transect) a $1 \mathrm{~m}^{2}$ plot was located and observed for seedlings of native plants and weeds. Numbers of native plant seedlings (abundance) and species (species richness) and numbers of species of exotic weeds (excluding Tradescantia) were counted. Also, the percent cover of Tradescantia was estimated within the same $1 \mathrm{~m}^{2}$ plots, using a foliar cover scale (Payton et al. 1999), and the values averaged to give a percent cover for each transect. The study sites were revisited annually each March from 2010-2012.

On each of the four sampling occasions, the counts from individual transects were totalled. For sites with more than one transect, the totals for the individual transects were averaged to give a mean for each site. In addition species richness indices were calculated using the Simpson's Index of Diversity (SID) (Simpson 1949),

$$
D=\sum_{i=1}^{S} \frac{n_{i}\left(n_{i}-1\right)}{N(N-1)}
$$

where $n_{i}=$ total number of individuals of a particular species, $i=$ the number of species, and $N=$ total number of organisms of all species in the sample. The complement of the result $(1-D)$ was used to derive the diversity index so that the values ranged from $0-1$, with 1 being the highest diversity.

\section{RESULTS}

The control histories both before and during the study period are given in Table 2 . All except Site 8 had been treated with herbicides before the survey began in 2009 and on various occasions since then. Sites 1, 2, 4 and 7 were treated annually for the four years of the study and the others less often.

The numbers of native seedling species per transect (species richness) increased at all sites 
Table 1 Description of forest sites, location, size, number of transects and dominant native species for eight sites in the survey. Values in parentheses after the forest site are the location in degrees latitude/ longitude; the size of the reserve and the number of transects.

\begin{tabular}{ll}
\hline Forest type/description & Dominant species ${ }^{1}$ \\
\hline Site 1: Wellington (-41.142 & $\mathbf{1 7 4 . 9 9 8 ;} \mathbf{1 1 4}$ ha; 1 transect) \\
$\begin{array}{ll}\text { Disturbed podocarp/tawa broadleaf } & \\
\text { exotic weeds. Adjacent to motorway. } & \text { tawa (Beilschmiedia tawa), mahoe (Melicytus ramiflorus), } \\
& \text { kawa kawa (Macropiper excelsum), tutu (Coriaria } \\
& \text { arboria), Pittosporum spp., titoki (Alectryon excelsus) }\end{array}$
\end{tabular}

Site 2: Wellington (-41.142 174.998; 114 ha; 2 transects)

Intact podocarp/broadleaf ${ }^{2}$.

Adjacent to motorway.

As above plus lancewoods (Pseudopanax spp.), rangiora

(Brachyglottis repanda) and tree-ferns (Cyathia and Dicksonia spp.)

Site 3: Wairarapa (-41.230 175.320; 3.62 ha; 2 transects)

Disturbed podocarp/broadleaf ${ }^{3}$.

Titoki, kahikatea (Dacrycarpus dacrydiodes), matai

Macrocarpa (Cupressus macrocarpa)

along margin

(Prumnopitys taxifolia), totara (Podocarpus totara), kowhai (Sophora spp), matipo (Pittosporum spp)

Site 4: Wairarapa (-41.214 175.190; 27.37ha; 2 transects)

Intact podocarp/broadleaf ${ }^{3}$

Black beech (Nothofagus solandri), kahikatea, titoki, matai, mahoe, nikau (Rhopalostylis sapida)

Site 5: Wairarapa (-40.706 175.652; $1.045 \mathrm{ha} ; 1$ transect)

Intact podocarp/broadleaf ${ }^{3}$

Matipo, totara, kahikatea, tawa, kaikomako (Pennantia corymbosa), ribbonwood (Hoharia spp.), lancewoods.

Site 6: Wairarapa (-40.391 $175.900 ; 80.9$ ha; 2 transects)

Disturbed podocarp/tawa forest ${ }^{3}$, many weeds present. Was grazed and logged

Kahikatea, totara, matai, rimu (Dacrydium cupressinum) tawa, titoki, hoheria, pukatea (Laurelia novae-zelandiae), divaricating shrubs (Coprosma spp.).

Site 7: Manawatu (-40.130 175.850; 340 ha; 3 transects)

Intact podocarp/broadleaf ${ }^{4}$

Totara, kahikatea, rimu, beech, matai, rata.

Site 8: Manawatu (-40.118 175.853; 340 ha; 1 transect)

Intact podocarp/broadleaf ${ }^{4}$

Same as Site 7 but with dense Tradescantia and little understory.

${ }^{1}$ Complete species lists can be found in Druce $(1975)^{2}$, Wassilieff et al. $(1986)^{3}$, Horizons Regional Council (2004) $)^{4}$.

over the 4 years (Table 3 ). There were differences between the sites, with the changes ranging from 2-14 new species. Similarly, the numbers of weed species (excluding Tradescantia) also increased over time at all sites (Table 3), with the changes ranging from $2-8$ new weed species. The percentage of plots with weeds present (a measure of spatial spread) also increased at all sites with the greatest increases occurring at Sites 1, 6, 3 and 7. Generally, the percentage of plots with weeds present increased along with the number of new weed species. The site with the most occurrences of new weed species (Site 1) was also the site with the lowest native species richness (Table 3) and this was also where substantial damage to the understory had resulted from the use of gun 
Table 2 Control histories and follow up spot-spray applications at eight study sites. Forest manager: DOC $=$ Dept of Conservation; $\mathrm{RC}=$ Regional Council. Follow-up control spot-spraying was carried out with a knapsack using triclopyr ${ }^{\star}$ or triclopyr plus picloram\#; - indicates no sprays were applied.

\begin{tabular}{|c|c|c|c|c|c|}
\hline Forest site & $\begin{array}{l}\text { Forest } \\
\text { manager }\end{array}$ & Control history pre-2009 & $2009-10$ & 2010-11 & 2011-12 \\
\hline Site 1 & $\mathrm{RC}$ & $\begin{array}{l}\text { First sprayed late } 2008 \text {, with gun/hose with } \\
\text { glyphosate and triclopyr }(0.6 \%) \text {. Missed } \\
\text { patches and substantial off-target damage to } \\
\text { trees and shrubs }\end{array}$ & $\star$ & $\star$ & $*$ \\
\hline Site 2 & $\mathrm{RC}$ & $\begin{array}{l}\text { First sprayed late } 2008 \text { with knapsack and } \\
\text { triclopyr }(0.6 \%)\end{array}$ & * & * & * \\
\hline Site 3 & DOC & $\begin{array}{l}\text { Sprayed Mar } 2008 \text { with knapsack and triclopyr } \\
(0.6 \%)\end{array}$ & \# & - & - \\
\hline Site 4 & DOC & $\begin{array}{l}\text { Annual spray with knapsack and triclopyr } \\
(0.6 \%) \text { since } 2005\end{array}$ & * & * & * \\
\hline Site 5 & DOC & Hand weeded early 2009 & \# & * & - \\
\hline Site 6 & DOC & $\begin{array}{l}\text { Recently sprayed Jan } 2009 \text { with gun/hose and } \\
\text { triclopyr }(0.6 \%) \text {, with substantial off-target } \\
\text { damage to trees and shrubs }\end{array}$ & - & * & - \\
\hline Site 7 & $\mathrm{RC}$ & $\begin{array}{l}\text { Controlling annually since } 2006 \text { with } \\
\text { knapsacks and triclopyr }(0.6 \%)\end{array}$ & * & * & * \\
\hline Site 8 & $\mathrm{RC}$ & $\begin{array}{l}\text { No previous control but margin of one plot at } \\
\text { end of transect sprayed } 2010\end{array}$ & - & - & - \\
\hline
\end{tabular}

and hose applications of triclopyr and glyphosate (Table 2). The most commonly found weed species over all sites were Solanum spp. (S. dulcamara, S. nigrum, S. chenopodoides), broad-leaved fleabane (Conyza sumatrensis), staggerweed (Stachys arvensis), creeping buttercup (Ranunculus repens) and cocksfoot (Dactylis glomerata).

The cover of Tradescantia increased at Sites 6, 2 and 4 and it decreased or stayed the same at the remainder (Table 3). The greatest change in the cover of Tradescantia occurred at Site 6 where it had increased more than four-fold (15-70\% cover) over the four assessments, as control was discontinued. At Site 8 the forest margin at one end of the transect was treated with glyphosate herbicide in 2010 and although the transect was not sprayed the cover of Tradescantia may have reduced on it as a consequence.

The lowest SID values calculated for the 4 years of data were for Site $1(0-0.63)$ because few native species were present there at any time (Table 3 ). The highest SID values were for Site 8 (0.83-0.91) where no spraying had been done. All other sites had SID values between 0.54 and 0.89 . However, SID values were variable and were influenced by large numbers of seedlings of the dominant species.

\section{DISCUSSION}

In studies of this type the question of whether the outcome of control is beneficial or not can be answered in several ways. For example, was the invasive weed in question effectively controlled or not and was it replaced by native species or by other weeds? In many studies, a reduction in the target weed is the only measure of success with no consideration of impacts on the native plant communities (Kettenring \& Adams 2011). This situation appears to be also evident in New Zealand forest ecosystem management as the initial survey showed. This is probably because biodiversity monitoring is expensive, timeconsuming and sometimes difficult to measure.

Using the results reported here an attempt was made to measure restoration success in terms 
Table 3 Change from 2009 - 2012 along $50 \mathrm{~m}$ transects in the numbers of native seedlings, native species, Simpson's index of diversity (SID), cover of Tradescantia (\%), numbers of weeds species (excluding Tradescantia) and percentage of plots with weeds.

\begin{tabular}{|c|c|c|c|c|c|c|c|}
\hline $\begin{array}{l}\text { Forest } \\
\text { site }\end{array}$ & Sample time & $\begin{array}{l}\text { No. native } \\
\text { seedlings }\end{array}$ & $\begin{array}{c}\text { No. native } \\
\text { species }\end{array}$ & SID & $\begin{array}{l}\% \text { cover of } \\
\text { Tradescantia }\end{array}$ & $\begin{array}{c}\text { No. weed } \\
\text { species }\end{array}$ & $\begin{array}{l}\text { Plots with } \\
\text { weeds (\%) }\end{array}$ \\
\hline \multirow[t]{5}{*}{ Site 1} & 2009 & 2 & 1 & 0 & 10 & 5 & 27 \\
\hline & 2010 & 16 & 3 & 0.34 & 5 & 5 & 18 \\
\hline & 2011 & 18 & 4 & 0.63 & 1 & 10 & 55 \\
\hline & 2012 & 20 & 3 & 0.28 & 2 & 14 & 91 \\
\hline & Change & 18 & 2 & - & -8 & 9 & 64 \\
\hline \multirow[t]{5}{*}{ Site 2} & 2009 & 4 & 2 & 0.64 & 1 & 3 & 36 \\
\hline & 2010 & 58 & 9 & 0.74 & 2 & 3 & 27 \\
\hline & 2011 & 184 & 14 & 0.81 & 1 & 8 & 77 \\
\hline & 2012 & 71 & 14 & 0.81 & 12 & 7 & 50 \\
\hline & Change & 67 & 12 & - & 11 & 4 & 14 \\
\hline \multirow[t]{5}{*}{ Site 3} & 2009 & 28 & 8 & 0.86 & 1 & 5 & 45 \\
\hline & 2010 & 121 & 16 & 0.83 & 1 & 2 & 27 \\
\hline & 2011 & 67 & 12 & 0.85 & 1 & 6 & 55 \\
\hline & 2012 & 78 & 15 & 0.85 & 1 & 7 & 73 \\
\hline & Change & 50 & 7 & - & $\mathbf{0}$ & 2 & 27 \\
\hline \multirow[t]{5}{*}{ Site 4} & 2009 & 56 & 13 & 0.87 & 2 & 1 & 5 \\
\hline & 2010 & 270 & 18 & 0.75 & 2 & 1 & 5 \\
\hline & 2011 & 370 & 26 & 0.89 & 4 & 2 & 14 \\
\hline & 2012 & 224 & 26 & 0.83 & 6 & 3 & 14 \\
\hline & Change & 168 & 13 & - & 5 & 3 & 9 \\
\hline \multirow[t]{5}{*}{ Site 5} & 2009 & 36 & 10 & 0.81 & 17 & 0 & 0 \\
\hline & 2010 & 145 & 12 & 0.66 & 2 & 1 & 9 \\
\hline & 2011 & 116 & 16 & 0.8 & 1 & 0 & 0 \\
\hline & 2012 & 128 & 16 & 0.88 & 16 & 2 & 9 \\
\hline & Change & 92 & 6 & - & -1 & 2 & 9 \\
\hline \multirow[t]{5}{*}{ Site 6} & 2009 & 4 & 2 & 0.54 & 15 & 1 & 5 \\
\hline & 2010 & 258 & 9 & 0.68 & 50 & 5 & 55 \\
\hline & 2011 & 138 & 13 & 0.66 & 45 & 7 & 77 \\
\hline & 2012 & 84 & 16 & 0.79 & 70 & 5 & 59 \\
\hline & Change & 80 & 14 & - & 55 & 5 & 55 \\
\hline \multirow[t]{5}{*}{ Site 7} & 2009 & 54 & 14 & 0.85 & 9 & 2 & 12 \\
\hline & 2010 & 486 & 21 & 0.59 & 1 & 6 & 42 \\
\hline & 2011 & 471 & 26 & 0.76 & 1 & 9 & 55 \\
\hline & 2012 & 480 & 25 & 0.65 & 1 & 9 & 39 \\
\hline & Change & 426 & 11 & - & -8 & 7 & 27 \\
\hline \multirow[t]{5}{*}{ Site 8} & 2009 & 9 & 8 & 0.83 & 55 & 0 & 0 \\
\hline & 2010 & 46 & 16 & 0.91 & 45 & 1 & 9 \\
\hline & 2011 & 28 & 11 & 0.91 & 30 & 0 & 0 \\
\hline & 2012 & 27 & 11 & 0.89 & 41 & 2 & 9 \\
\hline & Change & 18 & 3 & - & -14 & 2 & 9 \\
\hline
\end{tabular}


of native seedling regeneration, re-invasion by Tradescantia and invasion by other weeds. The SID values were used as an indicator of diversity of native species but these did not reflect the increases in numbers of native species that were evident. Although the numbers of new species generally increased over time, the diversity indices were influenced by a few species having high numbers of seedlings. In this case, the change in native species richness appears to be a better measure of success. It is interesting to note, however, that the site which had the highest SID values was where no control had been done (Site 8), suggesting that the control strategies may have negatively impacted on diversity at the other sites.

Using increases in native species richness and corresponding decreases in the invasive weed cover and lower numbers of weed species as the criteria for success, Sites 7, 3, and 4 had the best outcomes. These sites were also examples of intact forests where initial and follow-up spraying had been careful with little disturbance. Using the same criteria, Site 6 had the worst outcome of all because it had a large increase in Tradescantia cover and an increase in other weed species, even though the native species richness had increased there. This is probably a consequence of its spray history whereby the initial gun and hose application of herbicide controlled the Tradescantia but at the same time destroyed much of the understory. This resulted in an initial flush of seedlings of native species and weeds but the lack of sufficient follow-up spraying (only once since initial control) meant that the Tradescantia has reverted to pre-control levels. Furthermore, most of these native seedling recruits would inevitably be lost if further blanket spraying of the Tradescantia was done, or through increased competition from the weed if it were not (Standish et al. 2001; Hurrell et al. 2009). Site 1 also had a poor outcome because it had large increases in other weed species and few native species, despite the cover of Tradescantia decreasing there. The cause is also likely to be the substantial off-target damage to the understory in the initial gun/hose spray application. These results show that the more disturbance of the forest that occurs during spray operations, the less likely it will lead to a beneficial outcome.

At the only site where no control had been done (Site 8 ), there was relatively little change over time demonstrating how the high weed canopy prevents regeneration of native species and the lack of disturbance limits invasion by other weeds. Furthermore, it could be argued that none of the sites with Tradescantia control (Sites 1-7) had good outcomes because all had increases over time in both the number of new weed species and the percentage of plots with weeds present, indicating increasing spatial spread of weeds.

The work by Standish $(2001,2002)$ showed that Tradescantia reached maximum biomass in light levels as low as $10 \%$ full light. In many of these remnant forests the canopy has been severely degraded by the presence of Tradescantia and often by off-target damage during control operations (e.g. Sites 1 \& 6). In most cases it would take longer for the canopy to restore to $>90 \%$ shade than it would take for the Tradescantia to re-grow. It may take ca 20 years for a canopy to re-establish from planted saplings (Standish 2002) and even longer from seedlings.

Although the Tradescantia cover at most sites has remained at low levels (except for Site 6 ), further spraying will be needed to control it. Repeated control efforts spanning several years are usually needed to control Tradescantia (Brown \& Rees 1995; Standish 2002; G.A. Hurrell, unpublished data) but long-term control using herbicides (although more effective at reducing weed abundance) are more likely to impact negatively on native species (Kettenring \& Adams 2011). Although controlling weeds is often justified because of their negative impacts on native plants, control methods can also have detrimental effects on the native plant communities (Rinella et al. 2009) or result in the replacement of one exotic weed with another (Reid et al. 2009). This is because the removal of the target weed (and in some cases off-target damage to native plants) can result in decreased competition allowing more competitive, fastergrowing exotic plants to re-colonise and this consequence was evident from the present study. 
This study has shown that the outcomes of Tradescantia control operations currently being carried out in New Zealand forest remnants are highly variable in terms of native seedling regeneration and invasion by other weeds, and are influenced by management practices and ecological factors. In order to gauge the success or otherwise of any weed control effort it is necessary to quantitatively monitor the changes that occur not only to the target weed but to the native plants and the other invasive weeds as well.

\section{ACKNOWLEDGEMENTS}

We thank Michael Urlich (Greater Wellington Regional Council), Neil Gallagher (Horizons Regional Council) and Jenny Whyte (Department of Conservation, Masterton) for help finding the sites and for providing useful information and Dave Saville for help with designing the study. We acknowledge the Ministry of Science and Innovation (MSI) for funding this project through the Beating Weeds and Beating Weeds II programmes (C09X0504 and C09X0905, respectively).

\section{REFERENCES}

Brown D, Rees D 1995. Control of Tradescantia on Stephens Island. Ecological Management 3: 6-9.

Druce A 1975. Indigenous vascular plants of Barton's Bush (Trentham Memorial Park, Hutt Valley). D.S.I.R. Botany Division, Wellington, New Zealand. 3 p.

Horizons Regional Council 2004. Totara Reserve Ecosystem/habitat. Horizons Regional Council, Palmerston North, New Zealand. 7 p. Hurrell G, James T, Lamoureaux S, Lusk C, Trolove M 2009. Effects of rate of application of triclopyr on wandering Jew (Tradescantia fluminensis Vell.). New Zealand Plant Protection 62: 363-367.
Kettenring KM, Adams CR 2011. Lessons learned from invasive plant control experiments: a systematic review and meta-analysis. Journal of Applied Ecology 48: 970-979.

McCluggage T 1998. Herbicide trials on Tradescantia fluminensis. Conservation Advisory Science Notes. Department of Conservation, Wellington, New Zealand. 8 p.

Payton I, Pekelharing C, Frampton C 1999. Foliar browse index: a method for monitoring possum (Trichosurus vulpecula) damage to plant species and forest communities. Landcare Research (NZ) Ltd, Lincoln, New Zealand. $61 \mathrm{p}$.

Reid AM, Morin L, Downey PO, French K, Virtue JG 2009. Does invasive plant management aid the restoration of natural ecosystems? Biological Conservation 142: 2342-2349.

Rinella MJ, Maxwell BD, Fay PK, Weaver T, Sheley RL 2009. Control effort exacerbates invasivespecies problem. Ecological Applications 19: 155-162.

Simpson EH 1949. Measurement of diversity. Nature 163: 688.

Standish RJ 2002. Experimenting with methods to control Tradescantia fluminensis, an invasive weed of native forest remnants in New Zealand. New Zealand Journal of Botany 26: 161-170.

Standish RJ, Robertson AW, Williams PA 2001. The impact of an invasive weed Tradescantia fluminensis on native forest regeneration. Journal of Applied Ecology 38: 1253-1263.

Wassilieff MC, Clark DJ, Gabites I 1986. Scenic reserves of the lower north island: A botanical survey of scenic and allied reserves of Wellington, Horowhenua, and Wairarapa: Biological survey of reserves series: no. 14. Dept Lands and Survey, Wellington, New Zealand. 8 p. 